\title{
RESPONSE OF LENTIL PLANTS TO MICRONUTRIENT FOLIAR APPLICATION IN SILT CLAY LOAM SOIL Rahmou, A. A. ${ }^{1}$; N. I. Abd El-Kader ${ }^{2}$ and E. K. Mahmoud ${ }^{2}$. ${ }^{1}$ Soil, Water and Environment Res. Inst.,Agric. Res. Center, Giza, Egypt. ${ }^{2}$ Soil and Water Sciences Dept., Faculty of Agriculture at Tanta, Tanta University, Egypt \\ E-mail: nasserkamal@yahoo.com
}

\begin{abstract}
Micronutrients foliar application is much better than soil application to avoid not only nutrients fixation in the soil, but also leaching during irrigation. Two field experiments were carried out at El-Gimmiza Agricultural Research Station during the two successive growing seasons of 2005/2006 and 2006/2007 to study the effect of foliar application of the micronutrients ( $\mathrm{Fe}, \mathrm{Mn}, \mathrm{Zn}$ and $\mathrm{Cu}$ ) in a mixture on yield, yield components and seed chemical composition of lentil plant (lens Culinaris. Medic). The foliar treatments applied were: T1 ( 0.0 micronutrients), T2 ( $0.5 \mathrm{~g} / \mathrm{L}$ micronutrients), T3 (1.0 g/L micronutrients) and T4 (2 g/L micronutrients). The obtained results revealed that spraying micronutrients at rate $0.5 \mathrm{~g} / \mathrm{L}$ (T2) increased yield and yield components such as: plant height $(3.1 \%)$, number of branches $(7.8 \%)$, number of pods/plant $(15.9 \%)$, seed yield/plant $(30.8 \%), 1000$-seed weight $(9.4 \%)$ and seed yield $(10.2 \%)$ as well as seed contents of protein (9\%), K (31.1\%), Fe (21.4\%), Zn (12.3\%), Cu (8\%) and $\mathrm{Mn}(13.6 \%)$ compared with the control (T1). The application of micronutrients at rate $0.5 \mathrm{~g} / \mathrm{L}$ (T2) caused significant increase in yield and yield components compared with other treatments. Meanwhile T4 $(2 \mathrm{~g} / \mathrm{L})$ gave significant decreases in most studied traits compared to T2. Also, the highest values were recorded with variety of Giza 4 than Sina 1 in all treatments during the two growing seasons.

Keywords: Lentil plants, micronutrients foliar, clay soil
\end{abstract}

\section{INTRODUCTION}

Lentil (lens Culinaris. Medic) is considered one of the oldest cultivated crops, and the most nutritious food legumes. The lentil seed is an important source of protein for human consumption in Egypt. The productivity of lentil is affected by many factors among which is the fertilization by macro- and micro nutrients during various growth stages, where the fertilization with these elements is limiting and important factor in increasing the yield and seed quality. Since micronutrients affect directly photosynthesis, respiration, synthesis... etc, the presence or absence of any nutrient during a specific stage of plant growth might affect the growth pattern through alteration in metabolic processes (Eissa et al., 1992).

Using micronutrients as foliar fertilization is preferable than soil application to avoid not only nutrient fixation in the soil, but also leaching during irrigation. Hegazy et al. (1990) showed that, foliar application of micronutrients to soybean was much better than soil application. Negm and Zahran (2001) reported that supplying micronutrients to wheat plant as a foliar application at specific physiological growth stage is undoubtedly of great importance, especially in case of micronutrient deficient soils. 
$\mathrm{Mn}$ and $\mathrm{Zn}$ are known to displace Fe from chelate complexes and forming corresponding heavy metal chelates in soil, this phenomenon may be important either for limiting $\mathrm{Fe}$ uptake or reducing Fe-chelate translocation (Dahdoh, 1997).

Manchanda et al. (2006) studied the response of lentil to copper fertilization in a typic-udorthent and found that, dry matter yield of root and shoot increased significantly over the control with the application of $2.5 \mathrm{mg}$ $\mathrm{Cu} / \mathrm{kg}$ soil, and the yield declined sharply when applied at $5 \mathrm{mg} \mathrm{Cu} / \mathrm{kg}$ soil. . Higher contents of $\mathrm{Zn}, \mathrm{Cu}, \mathrm{Fe}$ and $\mathrm{Mn}$ were observed in roots compared to shoots, irrespective of $\mathrm{Cu}$ levels. The reduction in $\mathrm{Zn} / \mathrm{Cu}, \mathrm{Fe} / \mathrm{Cu}$ and $\mathrm{Mn} / \mathrm{Cu}$ ratio in both plant parts were observed with increasing copper applied.

Singh et al. (1985) found that Fe application increased lentil seed yield. Zinc treatment increased lentil yield but suppressed $\mathrm{Mn}$ content in lentil plants (Gupta et al. 1985). Gangwar and Singh (1986) found that Zinc application on lentil resulted in higher number of branches/plant, pods/plant and increased 1000-seed weight, seed yield/plant and seed yield/ha. But straw yield/ha was not significantly influenced by zinc application. Salehi et al. (2008) found that, the harvest index, seed yield per plant, pods per plant and biological yield were correlated with grain yield. In addition, harvest index, seed yield per plant, pods/plant and biological yield were the most important traits that have a relationship with grain yield. Okaz et al. (1994) found that $\mathrm{P}, \mathrm{K}$, protein, $\mathrm{Fe}$, $\mathrm{Mn}$ and $\mathrm{Zn}$ contents in seed were significantly increased by most micronutrients treatments. Abdel-Salam (1998) reported that foliar application of $\mathrm{Zn}$ significantly increased $\mathrm{Zn}$ content in grain. Ziaeian and Malakouti (2001) indicated that Fe, Mn and Zn fertilization caused significant increase in concentration and total uptake of the element in shoots.

The objective of this study is to evaluate the effect of micronutrients ( $\mathrm{Fe}, \mathrm{Mn}, \mathrm{Zn}$ and $\mathrm{Cu}$ ) as a foliar application on the biological yield of two varieties of lentil (Sina 1 and Giza 4) and its contents of some elements.

\section{MATERIALS and METHODS}

Two field experiments were carried out at El-Gimmiza Agricultural Research Station during the two successive growing seasons 2005/2006 and $2006 / 2007$ to study the effect of foliar application of the micronutrients, Fe, $\mathrm{Mn}, \mathrm{Zn}$ and Cu mixed at the ratio 3\%, $2 \%, 1.5 \%$ and $1 \%$ respectively applied in three doses $(0.5,1.0$ and $2.0 \mathrm{~g} / \mathrm{L})$, on yield, yield components and seed chemical composition of lentil plant. In this experiment, two varieties of lentil crop (Sina 1 and Giza 4) were seeded at rate of $50 \mathrm{~kg} / \mathrm{fed}$. A split blot design with three replicates was used, the main plots were assigned for varieties, while the sup plots were assigned for foliar treatments. The plot size was 10 $\mathrm{m}^{2}$ with 15 rows $(20 \mathrm{~cm}$. apart and $3.5 \mathrm{~m}$. long). Phosphorus and potassium fertilizers were applied before planting at the rate of $30 \mathrm{~kg} \mathrm{P} 2 \mathrm{O}_{5} / \mathrm{fed}$ using CaSuperphosphate $\left(15.0 \% \mathrm{P}_{2} \mathrm{O}_{5}\right)$ and $24 \mathrm{~kg} \mathrm{~K} \mathrm{~K}_{2} \mathrm{O} / \mathrm{fed}$ with potassium sulphate $\left(48 \% \mathrm{~K}_{2} \mathrm{O}\right.$, while nitrogen fertilizer was applied at $15 \mathrm{~kg} \mathrm{~N} / \mathrm{fed}$ as ammonium sulfate $(20.6 \% \mathrm{~N})$ after two weeks from sowing. Some physical and chemical properties of the experimental soil were presented in Table (1) 


\section{Treatments}

The micronutrients mixture was prepared by mixing $\mathrm{Fe}\left(\mathrm{FeSO}_{4}\right), \mathrm{Mn}$ $\left(\mathrm{MnSO}_{4}\right), \mathrm{Zn}\left(\mathrm{ZnSO}_{4}\right)$ and $\mathrm{Cu}\left(\mathrm{CuSO}_{4}\right)$ at the concentration of 3, 2, 1.5 and $1 \%$, respectively. The applied treatments were: T1 ( 0.0 micronutrients), T2 $(0.5 \mathrm{~g} / \mathrm{L}$ micronutrients $)$, T3 $(1.0 \mathrm{~g} / \mathrm{L}$ micronutrients) and T4 $(2 \mathrm{~g} / \mathrm{L}$ micronutrients), with triton-B $(0.1 \%)$ as wetting agent. The plants received two sprays at the beginning of flowering (45 days after sowing) and setting (early pod formation 60 days after sowing) stages. Spray solution volume for each treatment was at the rate of 400 liters/fed.

Random samples of ten guarded plants in each plot were taken at harvest to estimate the following characters: Plant height $(\mathrm{cm})$, numbers of branches and numbers of pods/plant, seed yield/plant (g), 1000-seed weight (g) and seed yield/fed. (arddab).

Seed samples of lentil were dried at $70^{\circ} \mathrm{C}$ for $48 \mathrm{~h}$, ground and digested using sulphuric acid and $\mathrm{H}_{2} \mathrm{O}_{2}$ methods to determine $\mathrm{N}, \mathrm{K}, \mathrm{Fe}, \mathrm{Mn}$, $\mathrm{Zn}$ and $\mathrm{Cu}$ concentrations.

Nitrogen was determined in lentil seeds by semi-micro kjeldahle method, as discrabed by A.O.A.C (1970). The protein (\%) in seed was calculated according to A.O.A.C (1970). Potassium was determined by flame photometer according to Jackson (1967). Micronutrient contents (Fe, Zn, Mn and $\mathrm{Cu}$ ) were estimated by using the atomic absorption spectrophotometer. Data were statistically analyzed according to Snedecor and Cochran (1967). The least significant difference (LSD) was used to compare the means.

Table 1: Some physical and chemical properties of the experimental soil

\begin{tabular}{|l|c|}
\hline \multicolumn{1}{|c|}{ Properties } & Value \\
\hline Sand \% & 15.37 \\
Silt \% & 44.67 \\
Clay \% & 39.96 \\
Textural class & Silt clay loam \\
Apparent density $\left(\mathrm{g} / \mathrm{cm}^{3}\right)$ & 1.31 \\
E.Ce ds/m & 2.06 \\
$\mathrm{pH}(1: 2.5$ suspension) & 7.86 \\
Organic matter \% & 2.48 \\
CaCO $\%$ & 3.84 \\
Available N $\mathrm{mg} / \mathrm{kg}$ & 25.4 \\
Available P $\mathrm{mg} / \mathrm{kg}$ & 7.25 \\
Available Fe mg/kg & 6.45 \\
Available Mn mg/kg & 1.99 \\
Available $\mathrm{Zn} \mathrm{mg/kg}$ & 0.87 \\
Available Cu mg/kg & 0.47 \\
\hline
\end{tabular}




\section{RESULTS AND DISCUSSION}

Data recorded in this study represent the mean values of the two investigated seasons 2005/2006 and 2006/2007. These results showed the effect of different doses of micronutrients foliar applied on yield, yield component and seed contents of some macro- and micronutrients.

\section{Yield and yield components}

\section{a)Effect of micronutrients}

The results in Table (2) showed that number of branches or pods/plant and weight/plant and 1000-seed weight were significantly affected by micronutrient application while the plant height and seed yield/fed showed insignificant response. However, the studied traits were generally reduced by increasing the rate of foliar applied micronutrients and T2 $(0.5 \mathrm{~g} / \mathrm{L})$ recorded the highest value. Micronutrient treatments T2 $(0.5 \mathrm{~g} / \mathrm{L})$ or T3 $(1.0 \mathrm{~g} / \mathrm{L})$ increased the studied traits to different extents compared with T1 (control) with no significant difference between them, while T4 (2.g/L) caused significant reduction in most traits compared to T1 or T2. The T4 $(2.0 \mathrm{~g} / \mathrm{L})$ gave significant reduction in number of branches or pods/plant, and seed weight/plant compared with T2 by $18.8 \%, 27.5 \%$ and $26.9 \%$ respectively. On the other hand, 1000-seed weight showed positive significant response to all micronutrient application by 8.7 - $9.4 \%$ over the T1 with no significant differences among the micronutrient treatments. Although, micronutrient application showed no significant effect on seed yield compared with the check treatment $(\mathrm{T} 1)$, the $\mathrm{T} 4(2.0 \mathrm{~g} / \mathrm{L})$ reduced it significantly by $14.5 \%$ compared with T2 $(0.5 \mathrm{~g} / \mathrm{L})$. This results are in agreement with those obtained by Gangwar and Singh (1986), Ghaly et al (1991), Okaz et al (1994) and Zeidan et al. (2006).

The effect of micronutrients on lentil yield and yield component my be due to the important function of $\mathrm{Fe}, \mathrm{Zn}$, Mo in plant metabolism especially in chlorophyll synthesis, photo syntheses, activation of different enzymes and finally in phytohormone regulation. Therefore, it is very important to add micronutrients such as $\mathrm{Fe}, \mathrm{Zn}$ and $\mathrm{Mn}$ in order to avoid the deficiency of these elements during the growth of lentil plant in sandy or clay soils.

Okaz et al (1994) reported that lentil plants responded significantly to micronutrients where the $\mathrm{Fe}+$ Mo gave the highest seed yield/fed than the other treatments. On the other hand, Sharief and Said (1998) found that foliar application with micronutrient either separately or in mixture significantly increased number of branches, pods/plant, 1000-seed weight and seed yield/fed. of lentil crop.

The response of lentil plants to $\mathrm{Fe}, \mathrm{Mn}$ and $\mathrm{Zn}$ application could be depend on the contents of these elements in the experimental soil. Singh (2001) concluded that the micronutrients deficiencies in form of chlorosis, which are of regular occurrence in groundnut grown on deficient soil, unless corrected by external application of micronutrients would result in significant loss of crop yield. The negative response of lentil plants to the T4 treatment could be attributed to the higher concentration of the applied micronutrients which led to the harmful effects on lentil growth and then on yield and its components. 
Table 2: Effect of micronutrients treatments on yield and yield component of lentil plant.

\begin{tabular}{|l|c|c|c|c|c|c|}
\hline Treatments & $\begin{array}{c}\text { Plant } \\
\text { height } \\
\text { (cm) }\end{array}$ & $\begin{array}{c}\mathbf{N}^{\circ} \text { of } \\
\text { branches/plant }\end{array}$ & $\begin{array}{c}\mathbf{N}^{\circ} \text { of } \\
\text { pods/plant }\end{array}$ & $\begin{array}{c}\text { Seed } \\
\text { weight } \\
\text { g/plant }\end{array}$ & $\begin{array}{c}\text { Seed yield } \\
\text { Arddab/fed }\end{array}$ & $\begin{array}{c}\mathbf{1 0 0 0}- \\
\text { seed } \\
\text { weight(g) }\end{array}$ \\
\hline T1 & $35.9 \mathrm{a}$ & $3.20 \mathrm{ab}$ & $37.43 \mathrm{ab}$ & $1.30 \mathrm{~b}$ & $3.24 \mathrm{ab}$ & $28.6 \mathrm{~b}$ \\
\hline T2 & $37.0 \mathrm{a}$ & $3.45 \mathrm{a}$ & $43.40 \mathrm{a}$ & $1.78 \mathrm{a}$ & $3.57 \mathrm{a}$ & $31.3 \mathrm{a}$ \\
\hline T3 & $37.4 \mathrm{a}$ & $3.10 \mathrm{bc}$ & $42.40 \mathrm{a}$ & $1.60 \mathrm{a}$ & $3.44 \mathrm{ab}$ & $31.1 \mathrm{a}$ \\
\hline T4 & $32.6 \mathrm{a}$ & $2.80 \mathrm{c}$ & $31.46 \mathrm{~b}$ & $1.30 \mathrm{~b}$ & $3.05 \mathrm{~b}$ & $31.1 \mathrm{a}$ \\
\hline L.S.D at 0.05 & $\mathrm{~N} . \mathrm{S}$ & $0.33^{* *}$ & $6.77^{* *}$ & $0.2^{* *}$ & $\mathrm{~N} . \mathrm{S}$ & $0.2^{*}$ \\
\hline
\end{tabular}

\section{b) Effect of lentil cultivars}

Data presented in Table (3) reveal that there are differences between sina 1 and Giza 4 cultivars concerning plant height, number of branches/plant, number of pods/plant and seed yield/fed. This results are in agreements with that obtained by Okaz et al (1994) and Nassar et al.(2004).

Lentil cultivar Giza 4 was characterized by those higher reproductive organs such as plant height and number of pods/plant, number of branches/plant,. This results could be explained on the basis of the genetic differences between the two cultivars (Osman et al. 2000).

Table 3: Effect of lentil cultivars on yield and yield components of lentil plant.

\begin{tabular}{|l|c|c|c|c|c|c|}
\hline Cultivars & $\begin{array}{c}\text { Plant } \\
\text { height } \\
\text { (cm) }\end{array}$ & $\begin{array}{c}\mathbf{N}^{\circ} \text { of } \\
\text { branches/plant }\end{array}$ & $\begin{array}{c}\mathbf{N}^{\circ} \text { of } \\
\text { pods/plant }\end{array}$ & $\begin{array}{c}\text { Seed } \\
\text { weight } \\
\text { (g/plant) }\end{array}$ & $\begin{array}{c}\text { Seed yield } \\
\text { (Arddab/fed) }\end{array}$ & $\begin{array}{c}\text { 1000- } \\
\text { seed } \\
\text { weight (g) }\end{array}$ \\
\hline Sina 1 & 31.5 & 2.73 & 22.9 & 1.2 & 2.7 & 29.2 \\
\hline Giza 4 & 39.9 & 3.55 & 54.4 & 2.1 & 3.91 & 38.0 \\
\hline
\end{tabular}

\section{c) Interaction effect}

Table (4) show the interaction effects between micronutrient treatments and lentil cultivars on yield and yield components of lentil plant. It had significant effect on all the studied characterise plant height, number of branches, number of pods, seed weight, 1000-seed weight and seed yield/ fed. The high effect was found with T2 with Giza 4, and the lowest effect on some characters was found with T4 with the same variety Giza 4. Generally, Giza 4 was the highly affected by the micronutrients treatments than Sina1 in all characters. This results were agreement with those obtained Nassar et al.,(2004) and Zeidan et al., (2006).

\section{Seed chemical contents}

\section{a) Effect of micronutrients}

Data reported in Table (5) reveal that seed contents of protein, $\mathrm{K}, \mathrm{Fe}$, $\mathrm{Zn}, \mathrm{Cu}$ and $\mathrm{Mn}$ were generally higher by foliar application of the studied micronutrients.

However,these contents were generally decreased in increasing the rate of micronutrients. 
Rahmou, A. A. et al.

4 
Seed contents of protein, $\mathrm{K}, \mathrm{Fe}$ and $\mathrm{Zn}$ showed pronounced increases over the control treatment due to foliar application of micronutrients especially T2 $(0.5 \mathrm{~g} / \mathrm{L})$ which induced augmentation in protein, $\mathrm{K}, \mathrm{Fe}$ and $\mathrm{Zn}$ over T1 (0 micronutrients) by $8.3,31.3,21.4$ and $12.3 \%$ respectively. On the other hand, seed contents of both $\mathrm{Cu}$ and $\mathrm{Mn}$ were slightly affected by micronutrient application. Moreover, foliar application of micronutrient at the higher rate $(2.0 \mathrm{~g} / \mathrm{L})$ was less effective on the above montioned seed constituents as shown in Table (5). Those results are in agreement with the characters of yield and yield component. Similar results were obtained by Ghaly et al. (1991), Okaz et al. (1994) and Zeidan et al. (2006).

Table 5: Effect of micronutrients treatments on some macro and micronutrients contents of lentil seeds.

\begin{tabular}{|l|c|c|c|c|c|c|}
\hline Treatments & $\begin{array}{c}\text { Protein } \\
(\%)\end{array}$ & $\mathbf{K}(\%)$ & $\begin{array}{c}\text { Fe } \\
(\mathbf{m g} / \mathbf{1 0 0 g})\end{array}$ & $\begin{array}{c}\text { Zn } \\
(\mathbf{m g} / \mathbf{1 0 0 g})\end{array}$ & $\begin{array}{c}\text { Cu } \\
(\mathbf{m g} / \mathbf{1 0 0 g})\end{array}$ & $\begin{array}{c}\text { Mn } \\
(\mathbf{m g} / \mathbf{1 0 0 g})\end{array}$ \\
\hline$T 1$ & 27.5 & 1.06 & 14.5 & 5.7 & 2.5 & 2.2 \\
\hline$T 2$ & 30.0 & 1.39 & 17.6 & 6.4 & 2.7 & 2.5 \\
\hline$T 3$ & 28.0 & 1.27 & 17.3 & 6.2 & 2.7 & 2.4 \\
\hline$T 4$ & 28.6 & 1.27 & 16.0 & 6.2 & 2.8 & 2.3 \\
\hline
\end{tabular}

\section{b) Effect of lentil cultivars}

Data presented in Table (6) reveal that there are differences between sina 1 and Giza 4 cultivars concerning protein (\%),K (\%), Fe, Zn, Cu and Mn $(\mathrm{mg} / 100 \mathrm{~g})$ in seeds of lentil plant. This results were agreement with those obtained by Okaz et al. (1994) and Nassar et al. (2004).

Seed of lentil cultivar Giza 4 were characterized by higher chemical constituents such as protein, $\mathrm{K}, \mathrm{Fe}, \mathrm{Cu}$ and $\mathrm{Mn}$ compared with Sina1. This results could be explained on the basis of the genetic differences between the two cultivars (Osman et al., 2000) and the high response of Giza 9 to micronutrient application than Sina 1.

Table 6: Effect of lentil cultivars on some macro and micronutrients contents of lentil seeds.

\begin{tabular}{|l|c|c|c|c|c|c|}
\hline Treatments & $\begin{array}{c}\text { Protein } \\
(\%)\end{array}$ & $\mathbf{K}(\%)$ & $\begin{array}{c}\text { Fe } \\
\mathbf{m g} / \mathbf{1 0 0 g})\end{array}$ & $\begin{array}{c}\mathbf{Z n} \\
\mathbf{m g} / \mathbf{1 0 0 g})\end{array}$ & $\begin{array}{c}\mathbf{C u} \\
\mathbf{m g} / \mathbf{1 0 0 g})\end{array}$ & $\begin{array}{c}\mathbf{M n} \\
\mathbf{m g} / \mathbf{1 0 0 g})\end{array}$ \\
\hline Sina 1 & 28.39 & 1.12 & 16.3 & 6.1 & 2.5 & 2.3 \\
\hline Giza 4 & 30.45 & 1.38 & 16.4 & 6.1 & 2.8 & 2.4 \\
\hline
\end{tabular}

\section{c) Interaction effect}

Data in Table (7) show the interaction effect between the micronutrient treatments and lentil cultivars on protein (\%), $\mathrm{K}(\%), \mathrm{Fe}, \mathrm{Zn}, \mathrm{Cu}$ and $\mathrm{Mn}(\mathrm{mg} / 100 \mathrm{~g})$ in seeds of lentil plant. The high effect on protein, $\mathrm{K}$, and $\mathrm{Fe}, \mathrm{Zn}, \mathrm{Cu}$ and $\mathrm{Mn}$ in seeds of lentil plant was found by T2 Giza 9. Generally, Giza 4 is the highly affected by the micronutrients compared to treatments Sina1 in all characters. This results are agreement with those obtained by Ghaly et al. (1991), Okaz et al. (1994) and Zeidan et al. (2006). 
Rahmou, A. A. et al.

7 
It could be concluded that, application of micronutrient $(\mathrm{Fe}+\mathrm{Zn}+\mathrm{Cu}$ $+\mathrm{Mn}$ ) as foliar fertilizer on the aerial parts at the rate of $0.5 \mathrm{~g} / \mathrm{L}$ mixer was the most effective treatment since it increased yield and yield components as well as the contents of lentil seeds of protein and micronutrients than the other treatments.

\section{REFERENCES}

Abd El-Salam A. A. (1998). Effect of soil land foliar application of nitrogen in combination with Zinc on the biomass yield and grain quality of faba been grown on lacustrine soil. Alex. J. Agric. Res., 43/ 129 - 139.

A.O.A.C (1970). Official methods of analsis $11^{\text {th }}$. Ed., Association of official Agriculture Chemists, Washington, DC.

Dahdoh, M.S.A. (1997). Iron-manganese-zinc relationships on broad bean grown on sandy soils. Egypt J. Soil Sci., 37(4):499-510.

Eissa, A.I.; M.A. Hammam; A.A. Sakr and E.A.Y. Kabbany (1992). Effect of $\mathrm{Zn}$ and $\mathrm{Mn}$ on yield, carbohydrate metabolism and some enzymes in wheat plants. Menofiya J. Agric. Res., 17(3):1001.

Gangwar, K.S. and Singh, N.P. (1986). Effect of Zinc fertilization on lentil. Lens Newsletter, 13:17-20.

Ghaly, S.; Osman, A. O. and Abd El-Aziz, I. M. (1991). The interaction of some micronutrients and rhizobia on lentil yield grown on sandy soils. Agric. Res. Review, Cairo, Egypt (under publish) (C.F. Proc. $6^{\text {th }}$ conf. Agron., Al-Azhar Unv., Cairo, Egypt. Sep. 1994, Vol. II: 737 - 752.)

Gupta, V.K.; Singh,B. and Bansal, R.K. (1985). Influence of mycrrohizal, Rhizobium and Zinc on growth, nodulation, zinc, copper and manganese content of lentil (Lens esculenta). Zentraibl.Microbiol. 140:465-9.(C.F. Zinc in Agric., 7(2):5134,1987).

Hegazy, M.H.; I. Fatma; M. El Hawary and W.N. Ghobrial (1990). Effect of micronutrient application and bradyrhizobium japnicum inoculation on soybean. Nnals Agric. Sci., Special Issue: 381-398.

Jackson, M. L. (1967). Soil chemical analysis, prentice Hall, of land on private Lim. Indian private limited, New Delhi, pp. 251-280.

Manchanda, J.S.; I.M. Chhibba and V.K. Nayyar (2006). Response of lentil (Lens culinaris L.) to copper fertilization in a typic udorthent. Research on Crops, 7 (1): 88 - 91.

Nassar, K.E.M.; Madiha M. Badran; M.M. El-Shony and A.O. Osman (2004). Response of two lentil cultivars to irrigation and phosphatic fertilization. Minufiya J. Agric. Res. Vol. 29 (1): $321-332$.

Negm, A.Y. and F.A. Zahran (2001). Optimization time of micronutrient application to wheat plants grown on sandy soils. Egypt J. Agric. Res., 79(3):813-823.

Okaz, A.M.A.; E.A. El-Ghareib; W. Kadry and A.Y. Negm, (1994). Micronutrient applications to lentil plants grown on newly reclaimed sandy soils. Proc. $6^{\text {th }}$ conf. Agron., Al-Azhar Unv., Cairo, Egypt. Sep. 1994, Vol. II: $737-752$. 
Osman, A.S.; Y.M.Y. Abido and S.M.M. Allam (2000). Response of soybean to phosphorus and $\mathrm{Zn}$ fertilization under irrigation regime. Annal Agric. Sci., Ain Shams Univ., 45 (1): 229 - 238.

Salehi, M.; A. Haghnazari; F. Shekari and A. Faramarzi (2008). The study of seed yield and seed yield components of lentil (Lens Culinaris Medik) under normal and drought stress conditions. Pakistan J. of Biological Sci., II (5): 758 -762.

Sharief, A.E. and E.I. M. Said (1998). Response of lentil (lens cultinaris, Med.) Productivity to phosphorus fertilizer levels and some micronutrients. Proc. $8^{\text {th }}$ conf. Agron., Suez Canal Univ., Ismailia, Egypt, 28 - 2ç Nov. pp: $326-334$.

Singh, A.L. (2001). Yield losses in groundnut due to micronutrient deficiencies in calcareous soil of India. In W.J. Horst, Schenk, M.K., (eds.) Plant Nutrition-food security and sustainability of agroecosystems. Kluwer Acadmic Publishers, Netherland: 838 -839.

Singh, B.P.; Sakal, R. and Singh, A.P. (1985). Response of lentil varieties to iron application on highly calcareous soils of Bihar. Indian J.Agric. Sci.,55:56-58.

Sndecor, G. W. and Cochran, W.G. (1967). Statistical methods; Oxford and I. B. H. Publishing G. $6^{\text {th }}$ Ed. pp. 299-310.

Zeidan, M.S.; M. Hozayn and M.E.E. Abd El-Salam (2006). Yield and quality of lentil as affected by micronutrient deficiencies in sandy soils. J. of Applied Sci. Res., 2(12): $1342-1345$.

Ziaeian, A.H. and M.J. Malakouti (2001). Effect of Fe, Mn, $\mathrm{Zn}$ and $\mathrm{Cu}$ fertilization on yield and grain quality of wheat in the calcareous soils of Iran: In W.J. Horst, Schenk, M.K., (eds.) Plant Nutrition-food security and sustainability of agroecosystems. Kluwer Acadmic Publishers, Netherland: $840-841$.

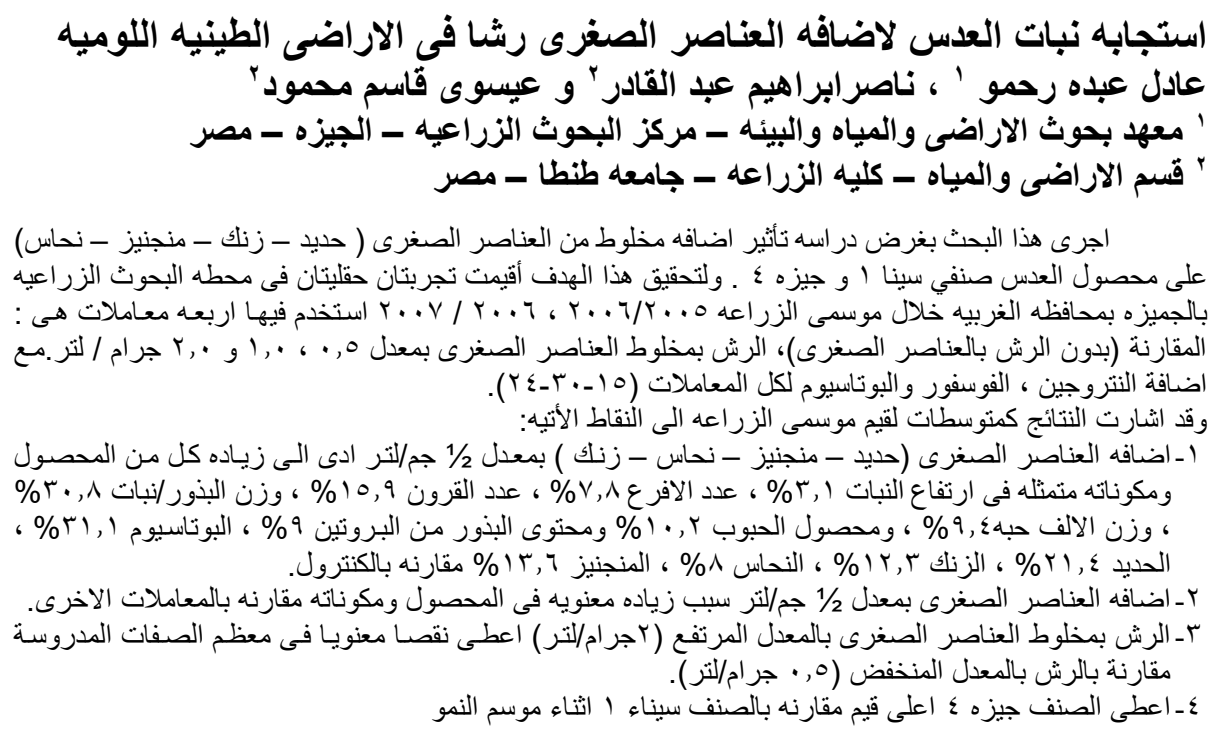


J. Agric. Sci. Mansoura Univ., 34 (1): 703 - 712, 2009

Table 4: The interaction effect between the micronutrients treatments and lentil cultivars on yield and yield component of lentil plant.

\begin{tabular}{|c|c|c|c|c|c|c|c|c|c|c|c|c|}
\hline \multirow[t]{2}{*}{ Treatments } & \multicolumn{2}{|c|}{$\begin{array}{l}\text { Plant height } \\
\text { (cm) }\end{array}$} & \multicolumn{2}{|c|}{$\begin{array}{c}\mathrm{N}^{\circ} \text { of } \\
\text { branchs/plant }\end{array}$} & \multicolumn{2}{|c|}{$\mathrm{N}^{\circ}$ of pods/plant } & \multicolumn{2}{|c|}{$\begin{array}{l}\text { Seed weight } \\
\text { g/plant }\end{array}$} & \multicolumn{2}{|c|}{$\begin{array}{l}\text { Seed yield } \\
\text { Arddab/fed }\end{array}$} & \multicolumn{2}{|c|}{$\begin{array}{c}1000- \\
\text { seed weight }\end{array}$} \\
\hline & Sina 1 & Giza 4 & Sina 1 & Giza 4 & Sina 1 & Giza 4 & Sina 1 & Giza 4 & Sina 1 & Giza 4 & Sina 1 & Giza 4 \\
\hline T1 & $31.7 \mathrm{~b}$ & $40.3 \mathrm{a}$ & $6 \mathrm{~b}$ & $3.8 \mathrm{a}$ & $22.15 b c$ & $52.72 \mathrm{a}$ & $1.1 \mathrm{~b}$ & $1.7 \mathrm{a}$ & $65 \mathrm{c}$ & $3.83 a b$ & $1.2 \mathrm{~b}$ & $6.0 a$ \\
\hline T2 & $31.6 \mathrm{~b}$ & $42.2 \mathrm{a}$ & $3.0 \mathrm{~b}$ & $3.9 \mathrm{a}$ & $25.90 \mathrm{bc}$ & $60.92 \mathrm{a}$ & $1.3 \mathrm{~b}$ & $2.0 \mathrm{a}$ & $2.93 \mathrm{c}$ & $4.2 \mathrm{a}$ & $24.5 \mathrm{~b}$ & $38.0 \mathrm{a}$ \\
\hline T3 & $32.5 \mathrm{~b}$ & $42.2 \mathrm{a}$ & $2.7 \mathrm{~b}$ & $3.5 \mathrm{a}$ & $28.3 \mathrm{C}$ & $56.5 \mathrm{ab}$ & $1.2 \mathrm{~b}$ & $2.0 \mathrm{a}$ & $2.81 \mathrm{c}$ & $4.07 \mathrm{ab}$ & $23.0 \mathrm{~b}$ & $39.0 a$ \\
\hline T4 & $30.2 \mathrm{~b}$ & $35.0 \mathrm{ab}$ & $2.6 \mathrm{~b}$ & $3.0 \mathrm{~b}$ & $15.37 d$ & $47.55 \mathrm{~b}$ & $1.0 \mathrm{~b}$ & $1.7 \mathrm{a}$ & $2.52 \mathrm{c}$ & $3.57 \mathrm{~b}$ & $23.1 \mathrm{~b}$ & $39.0 \mathrm{a}$ \\
\hline L.S.D at 0.05 & \multicolumn{2}{|c|}{$8.14^{*}$} & \multicolumn{2}{|c|}{$0.46^{*}$} & \multicolumn{2}{|c|}{$10.73^{*}$} & \multicolumn{2}{|c|}{0.4 * } & \multicolumn{2}{|c|}{$0.56^{*}$} & \multicolumn{2}{|c|}{$3.3^{*}$} \\
\hline
\end{tabular}


Rahmou, A. A. et al.

Table 7: The interaction effect between the micronutrients treatments and lentil cultivars on some macro and micronutrients contents of lentil seeds.

\begin{tabular}{|c|c|c|c|c|c|c|c|c|c|c|c|c|}
\hline \multirow[t]{2}{*}{ Treatments } & \multicolumn{2}{|c|}{$\begin{array}{c}\text { Protein } \\
\text { (\%) }\end{array}$} & \multicolumn{2}{|c|}{$\begin{array}{c}\mathrm{K} \\
(\%)\end{array}$} & \multicolumn{2}{|c|}{$\begin{array}{c}\mathrm{Fe} \\
(\mathrm{mg} / 100 \mathrm{~g})\end{array}$} & \multicolumn{2}{|c|}{$\begin{array}{c}\mathrm{Zn} \\
(\mathrm{mg} / 100 \mathrm{~g})\end{array}$} & \multicolumn{2}{|c|}{$\begin{array}{c}\mathrm{Cu} \\
(\mathrm{mg} / \mathbf{1 0 0 g})\end{array}$} & \multicolumn{2}{|c|}{$\begin{array}{c}\text { Mn } \\
(\mathrm{mg} / 100 \mathrm{~g})\end{array}$} \\
\hline & Sina 1 & Giza 4 & Sina 1 & Giza 4 & Sina 1 & Giza 4 & Sina 1 & Giza 4 & Sina 1 & Giza 4 & Sina 1 & Giza 4 \\
\hline T1 & 27.5 & 28.25 & 0.98 & 1.14 & 14.3 & 14.6 & 5.9 & 5.5 & 2.4 & 2.6 & 2.1 & 2.2 \\
\hline T2 & 30.0 & 31.31 & 1.3 & 1.47 & 17.5 & 17.7 & 6.3 & 6.4 & 2.6 & 2.7 & 2.4 & 2.5 \\
\hline T3 & 28.0 & 30.75 & 1.08 & 1.45 & 17.0 & 17.5 & 6.2 & 6.2 & 2.5 & 2.8 & 2.3 & 2.4 \\
\hline T4 & 28.06 & 31.5 & 1.1 & 1.44 & 15.2 & 15.7 & 6.2 & 6.1 & 2.6 & 2.9 & 2.3 & 2.3 \\
\hline
\end{tabular}

